\title{
ENVIRONMENTAL ACCOUNTING ON FINANCIAL PERFORMANCE AND REPUTATION OF MINING COMPANY IN INDONESIA
}

\author{
Naila Najihah \\ naila.najihah@unissula.ac.id \\ Maya Indriastuti \\ Universitas Islam Sultan Agung \\ J1. Kaligawe Raya, Semarang 50112, Indonesia
}

received: 1/7/19; revised: 21/10/19; approved: 29/6/20

\begin{abstract}
This research analyzes and tests empirically on how environmental accounting application can improve the company's performance and reputation. The company has a strategic role in the development of national economy. They are not only contributing to the economic growth in Indonesia but also absorb the workforce in large quantities. The population in this research is all manufacturing companies listed on the Indonesia Stock Exchange in 2016-2018. Samples determined using purposive sampling, which are active mining companies on the Indonesia Stock Exchange in 2016-2018. From this sampling method, the final samples used in this research are 60 firm year samples (20 companies $x 3$ years). The data used is secondary data and had analyzed using simple regression analysis. The results show that the implementation of environmental accounting gives positive impact on financial performance and company reputation. The increasing quality of financial performance and intrinsic reputation is established by the presence of environmental quality and social responsibility undertaken by the company.
\end{abstract}

Keywords: enviromental accounting; financial performance; reputation; mining companies

\section{INTRODUCTION}

The company's performance is a formal effort implemented by company to evaluate the efficiency and effectiveness of company activities that have been implemented over a certain period of time. "In 2018, 140 issuers recorded net profit increased by $8 \%$ or equivalent to $\mathrm{Rp} 19$ trillion. The total profit increases from $\mathrm{Rp}$ 230 trillion to $\mathrm{Rp} 248$ trillion. In terms of income, it increased by $12 \%$ (increased $\mathrm{Rp} 123$ trillion) from $\mathrm{Rp}$ 1,725 trillion to $\mathrm{Rp} 1,965$ trillion. In the asset post, there is an increase of 9\% (increased $\mathrm{Rp} 624$ trillion) from $\mathrm{Rp}$

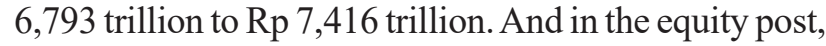
there is an increase of $8 \%$ or $\mathrm{Rp} 152$ trillion, from $\mathrm{Rp}$ 1,821 trillion to Rp 1,974 trillion" (www.cnbcindonesia. com). If it is elaborated deeper in terms of sectoral, the mining sector is experiencing the highest growth for $23 \%$ and followed by trade, service and investment sectors up to $17 \%$ (www.cnbcindonesia.com).

The data of increased financial performance above impacts the company's reputation. According to (Arshad, et. al., 2012; Koning, 2017), financial performance and company's reputation will improve when a company involves in Corporate Social Responsibility and disclose their annual statement. It is because the company considered to have company's value and positive intangible asset in many aspects such as attracting customer to generate investment interest, attracting the best talent, employee's motivation imrove the employee's satisfaction, generating media coverage in positive way, and receiving positive comments. The research result is consistent with research result from Borghesi, et. al., (2014) which stated, the company's ability in interacting with its environment will influence the company's reputation towards stakeholder, so that the stakeholder's trust to the company will increase if the communication runs well.

The main purpose of this environmental accounting is to correct information gaps which rise because of the environmental costs and damage also the use of this information are not identified, in order to support business decisions. Research on environmental accounting is based on the perspective that waste and emissions (non-product outputs) generated by companies often create externalities or effects for environment around companies that actually reflect the inefficient operations. The only thing that the company can produce is goods or service for sale. Even if the waste can be sold, it shows an inefficient production process. The company buys energy, water and materials to support its activities. 
Environmental accounting is considered because it becomes a concern for shareholders by reducing the costs associated with the environment (for example: pollution) with expectation by reducing environmental costs it will create a good environmental quality (Dashwood, 2014). The stimulant of environmental accounting is a tendency to environmental awareness. Environmental accounting identifies, assesses and measures the important aspects of the company's socio-economic activities in order to maintain the quality of environment in accordance with the objectives (Fasua, 2011; IFAC, 2005), so that the company can not process resources without paying attenting to its impact on society. The understanding of environmental accounting relevance is vary depend on the perspective of professionals and the practitioners' functional orientation. According to stakeholder theory (Freeman \& Reed, 1983), company is not only responsible for capital owners (shareholder) who are limited to economic indicators, but also social and environmental responsibilities. Stakeholders are internal and external parties such as governments, competitor companies, local communities, employees, communities and the environment. Business environment has a strong influence on corporate organization, moreover when the business is not limited by country territory (borderless world), the switch of hard technology to smart technology and other fundamental changes impact the policy to be taken by the company's management.

The company also uses energy, water and materials that are not part of the final product but it is needed, such as water to wash raw materials and fuel to run the engine. The material is ultimately also a waste that pollutes the surrounding environment and damages human health and other ecosystems such as plants and animals. The other environmental impacts related to the final product are the remaining use of products and packaging that are discarded by consumers and also damaging the environment. The impact is not only pollution from waste produced during operation, but also erosion or damage to surface and vegetation, precipitation on water surface, as well as food disturbance, reproduction and animal migration. In addition, it also impacts the local communities that depend on the environment to obtain food and clean water. Depreciation of natural resources that can not be renewed or later updated is also a serious problem. In order to manage and reduce the environmental impact of products and production processes, the company must have accurate data on the number and objectives of all energy, water and materials used. It should be known how much it is used, how it becomes the final product and how it becomes waste. Therefore, environmental preservation provides benefits for both the surrounding community and also for the company, especially the companies that utilize the environment and benefit from its environment (Henri \& Journeault, 2010; Mishra \& Suar, 2010).
Empirical evidence related to the influence of environmental accounting with financial performance has been conducted by previous researchers, Maqbool \& Zameer (2018) found that corporate social responsibility has significant positive influence to financial performance. Similar results also stated by (Arshad, et al., 2012; Galant \& Cadez, 2017; Koning, 2017; Rodriguez-Fernandez, 2016) that the corporate social responsibility positively affects the company's performance. The other results suggested by (MirallesQuiros, et. al., 2016) that if the company implements the corporate social responsibility and environmental management well then it will increase the value of the company. (Fiori, et. al., 2015; Stekelenburg, et. al., 2015; Weir, 2010) concluded that companies that have high social performance will have an impact on the company's growth, that is increasing company revenue, reflected through the increase of the stock price. Pan, et. al., (2014) stated, a positive relationship between CSR and financial performance. Guenster, et. al., (2011) reported the implementation of environmental accounting in correlation with the company's financial performance. (Fasua, 2011) mentioned that environmental accounting provides environmental management information to assist management in deciding prices, controlling overhead and reporting environmental information to the public. The disclosure of environmental management reports in annual report is form of social responsibility to determine the ecological impact of company's economic achievement. But in reality, the disclosure of environmental accounting in developing countries is still very low.

CSR disclosure initiatives can be used as business strategy by the company to improve the company's reputation and financial performance. In Islamic law, an activity is not only intended to meet the needs of material, but also must be based on religious responsibility. Based on the exposure of predictor variable in improving financial performance and reputation have been widely conducted research. Koning (2017) stated that the disclosure of Corporate Social Responsibility has a significant positive impact on the company's reputation. According to Koning, the implementation of CSR is not only seen as a promotional tool but can be seen as a competitive advantage in the company's business strategy. CSR can give a positive image to the company that further positive response is implemented by consumers through the purchase of the company's products so that the number of products sold will improve the company's financial performance. (Hussainey \& Salama, 2010; Kayondo, et. al., 2015; Lourenco, et. al., 2014; Maden, et. al., 2012; Walter, 2012) also agree that CSR has a significant positive impact on the company's reputation. The other research that has similar results (Arshad, et. al., 2012; Borghesi, et al., 2014; Gazzola, 2014; Stuebs, et. al., 2011) suggested that CSR has a significant positive impact on the company's reputation (Figure 1). 


\section{METHODS}

This type of this research is quantitative research, a study that emphasizes the theories testing through research variables measurement by numbers and conducting data analysis with statistical procedures (Indrianto and Supomo, 2014). The population of this research is all manufacturing companies listed on the Indonesia Stock Exchange in 2016-2018. Sampling technique uses sampling purposive based on criteria: (1) The mining companies listed on the Indonesia Stock Exchange and published the annual report in 2016-2018; (2) Mining companies that have been ranked on the company's performance rating program (PROPER) in 2016-2018; and (3) mining companies that have completed data related with research variables. Based on the criteria, the total sample used is 60 companies (20 companiesx 3 years). The reason for the company's elections is that companies belong to the industrial sector are seen that their operations and production activities actually consider to have a lot of conflicts with the environment.

The Data related to environmental accounting variables is PROPER rating obtained from the Ministry of Environment database (www.menlh. com). Data related with the financial performance variables obtained from the company's annual report published and available on the official website of Indonesia Stock Exchange (www. idx. Co. id). Company's reputation variable retrieved from the Global Reporting Initiative (2015). Type of data used in this research is secondary data. The environmental accounting variable uses an environmental disclosure proxy that is measured by using index that include 4 categories with 29 item disclosures (Clarkson, et. al., 2008). This measurement is done by matching the item on the check list with the company's disclosed item. If item $\mathrm{y}$ is disclosed then given a value of 1 , if Item $\mathrm{y}$ is not disclosed then given a value of 0 on the check list. The result of the items disclosure obtained from each company and the index is calculated with Global Reporting Initiative proxy (2015).

The financial performance variable uses return on asset (ROA) proxy, which is calculated by dividing the company's net profit (usually annual revenue) by its total assets and displayed as percentage (\%). Company's reputation variable uses Global Reporting Initiative (2015) with total 35 items for general standards disclosure.

All research data is analyzed by simple linear regression analysis. Linear regression analysis is used to predict the value of dependent variable based on other variable value and to see the influence of independent variable (X) towards (Y) (Ghozali, 2016).
The regression equation is as follow:

$$
\begin{aligned}
\mathrm{FP} & =\alpha+\beta \mathrm{EA}+\mathrm{e} . \\
\mathrm{REPU} & =\alpha+\beta \mathrm{EA}+\mathrm{e} .
\end{aligned}
$$

Description:

FP : Financial Performance

REPU: Reputation

$\alpha \quad$ : Constanta

$\beta \quad$ : Regression Coefficient

EA : Environmental Accounting

e : error

\section{RESULT}

Descriptive statistics can describe the data of each variables used in the research concept. Table 1 shows the descriptive statistics of the variables used in this research.

The financial performance variables that are proscribed with return on asset (ROA) have the smallest (minimum) value of- 0.1682 and the largest (maximum) value of 0.4922 . The average of ROA's 40 companies is 0.0819 , it shows that every Rp 1 mining company's assets can generate Rp 0.0819 in profit. The standard value of ROA's deviation is 0.0903 (above average), which means that ROA has a high level of data variation.

The company's reputation has the lowest value of -0.930 maximum value of 1.430 mean -0.020 , and standard deviation of 0.510 . These results show that standard deviation is greater than the mean, which means the company's reputation has great fluctuations. The mean value of -0.020 shows an average mining company experience a decrease in the share price during 2016-2018 period.

Environmental accounting has lowest value of 0.400 , maximum value of 0.800 mean 0.580 , and standard deviation of 0.080 . These results show that standard deviation is smaller than the mean, which means the CSRI has small fluctuations. The mean value of 0.580 shows an average mining company already reveal indicator of 53 from total of 91 indicators that should be disclosed in the GRI G4.

The simple linear regression result (Table 2) indicates that the independent variable (environmental accounting) has a low ability to explain the dependent variable (financial performance) that is equal to $13.6 \%$ and the rest is explained by other variables outside the model. The Environmental accounting has a positive and significant effect on the company's financial performance. It is seen from the calculated $t$ value of 4.788 with a significance of $0.013(\alpha<5 \%)$. It means that the hypothesis $(\mathrm{H} 1)$ which stated that environmental accounting disclosure positively affect the company's financial performance is proven, $\mathrm{H} 1$ is accepted. 
The simple linear regression result (Table 3) indicates that the independent variable (environmental accounting) has a low ability to explain the dependent variable (reputation) that is equal to $14.4 \%$ and the rest is explained by other variables outside the model. The environmental accounting variables have a positive and significant effect on the company's reputation. It is seen from the calculated t value of 5.659 with significance of $0.000(\alpha<5 \%)$. It means that the hypothesis (H2) which stated that environmental accounting disclosure positively influential towards proven company's reputation, $\mathrm{H} 2$ is accepted.

\section{DISCUSSION}

The t-test results show that the disclosure of environmental accounting has significant positive effect on the company's financial performance with positive regression coefficient of 1.459 with significance rate of 0.013 smaller than $\alpha 5 \%$. Based on the analysis results of each hypothesis test, obtained by the results of a positive environmental accounting disclosure on the company's financial performance, $\mathrm{H} 1$ is accepted. It means, the broader environmental accounting disclosure causes the company's financial performance to increase. This results in line with signal theory stated that the executive party of the company have better information about the company will be encouraged to deliver the information to potential investors where the company can increase the company's value through its reporting by sending signals through its annual report (Scott, 2012).

The research conducted by (Maqbool \& Zameer, 2018) stated that the implementation of green accounting has a significant and positive influence on financial performance. Green accounting is not limited to financial accounting, but it is also applied in accounting management, accounting management environment is used to monitor and evaluate the efficiency of resource usage, decrease the environmental effect from company's operation (Chetty, et. al. 2015). By the implementation of green accounting, the company will be able to follow the flow of costs used for the product, so the company, shareholders, and stakeholders know the load size incurred with the achievement of profit and company sales. Practically, the implementation of green accounting has a positive impact on the company's financial performance, that is the increase of positive perception from consumers that ended up in increasing the volume of sales and profits of the company.

The results of this study are consistent with the research results from (Guenster, et. al., 2011; Arshad, et. al., 2012; Pan, et. al., 2014; Galant \& Cadez, 2017; Koning, 2017; Rodriguez-Fernandez, 2016) that environmental accounting through its corporate social responsibility program positively affects the performance of the company. Other results are strengthened by (Mirrales-Quiros, et. al., 2016) that if the company implements the corporate social responsibility and environmental management well then it will increase the value of the company. (Fiori, et. al., 2015; Stekelenburg, et. al., 2015; Weir, 2010) concluded that companies that have high social performance will have an impact on the company's growth, in increasing company revenue, reflected through the increase of the stock price.

The t-test results showed that environmental accounting disclosure give significant positive influence to company's reputation with positive regression coefficient of 2.699 and significance rate of 0.000 smaller than $\alpha$ ( 5 percent). Based on the analysis results of each hypothesis test, obtained the environmental accounting disclosure results give positive influence to company's reputation, the $\mathrm{H} 2$ is accepted. It means that the broader environmental accounting disclosure causes the company's reputation to increase. These results in line with the signal theory which stated that the executive party of the company which have better information about the company will be encouraged to deliver the information to potential investors where the company can increase the company's value through its reporting by sending signals through its annual report (Scott, 2012).

Signals can be promotions or other information which stated that the company is better than other companies. Environmental accounting disclosure can be used by management to show the shareholders or investors that the company is better than other companies, as the form of responsibility for the entire impact of the company activities. Corporate Social responsibility provides information to investors about future returns. Corporate social responsibility in accordance with the expectations of stakeholders can be accepted as positive signal. The stakeholders theory stated that company voluntarily discloses environmental, social, and intellectual performance information, exceeding the demand of its face to meet actual and recognized expectations by stakeholders.

The company is required to be sensitive to the current trend of investors who will invest in a company with good business ethics, care about environmental impacts and have corporate social responsibility towards its stakeholders and the environmental accounting can facilitate the stakeholder needs of such social information (Mirrales-Quiros, et. al., 2016). The main objective is to help the company's managers to understand the stakeholders environment and to manage more effectively between the existence of their company's relationships and help the company's managers in increasing the impacts' value of their activities and minimize losses to stakeholders. The company not only operates for its own sake, the company must also be able to provide benefits to other stakeholders (IFAC, 2005). Each company is required to demonstrate responsibility to all stakeholders, not only from within the company but also from outside the company, which also includes 
responsibility to the environment. This proportion is supported by research from (Mishra \& Suar, 2010) who found that company can build a positive reputation by demonstrating responsibility in environmental and social preservation. In this case, corporate social responsibility can promote the company's reputation.

The results of this study provide support to the research results conducted by (Dashwood, 2014) that CSR activities such as charitable contributions and environmentally friendly practices enable the company to offset the business issues as the result of irresponsible action in the past. (Gazzola, 2014) stated CSR has significant positive impact on the company's reputation, which means, increased intrinsic reputation is established due to environmental quality and social responsibility. Koning (2017) stated that the implementation of CSR is not only seen as a promotional tool but can be seen as a competitive advantage in the company's business strategy. Hussainey \& Salama (2010; Kayondo, et al., (2015); Lourenco, et. al., (2014); Maden, et al., (2012); Walter, (2012) mentioned that CSR can give a positive image to the company that further positive response is implemented by consumers through the purchase of the company's products so that the number of products sold will improve the company's financial performance. The findings are similar to the findings of (Arshad, et al., 2012; Borghesi, et al., 2014; Stuebs, et al., 2011) that CSR has a significant positive impact on the company's reputation.

\section{CONCLUSION}

By the increasing environmental damage and increasing public awareness to maintain environment, the company as part of the environment is also required to observe environmental sustainability. The company itself is a legal entity which reponsible for the management of its company to shareholders and stakeholders, so the management should be able to demonstrate good performance to the interested parties related to financial performance and impact on the company's reputation. Disclosure of environmental aspects in financial statements can protect stakeholders from merely obtaining an environmentally friendly organizational image.

Low capability of independent variables (environmental accounting) in explaining the dependent variables (financial performance and reputation) is below $50 \%$. Therefore, the future research can add other variables, such as environmental costs, environmental performance, and many others.

The results of this study are expected: (1) mining companies further increase the amount of information related to environmental accounting so it is relevant for decision making. The success of environmental accounting does not only depend on the provisions in classifying all costs, but the ability and accuracy of company accounting data in suppressing the environmental impacts arising from company activities; and (2) the government will further improve the quality of standardization in setting regulations related to the need for disclosure of ICSR in Indonesia, not only in the sectors of mining companies but in all sectors including non-public companies. Standardization will make it easier for companies to implement existing policies and make it easier for regulators to evaluate the implementation of environmental accounting disclosure.

\section{REFERENCES}

Arshad, R., Othman, S. and Othman, R., 2012. Islamic corporate social responsibility, corporate reputation and performance. World Academy of Science, Engineering and Technology, 64(4), pp.1070-1074.

Borghesi, R., Houston, J.F. and Naranjo, A., 2014. Corporate socially responsible investments: CEO altruism, reputation, and shareholder interests. Journal of Corporate Finance, 26, pp.164-181.

Chetty, S., Naidoo, R. and Seetharam, Y., 2015. The impact of corporate social responsibility on firms' financial performance in South Africa. Contemporary Economics, 9(2), pp.193-214.

Clarkson, P.M., Li, Y., Richardson, G.D. and Vasvari, F.P., 2008. Revisiting the relation between environmental performance and environmental disclosure: An empirical analysis. Accounting, organizations and society, 33(4-5), pp.303-327.

Dashwood, H.S., 2014. Sustainable development and industry self-regulation: developments in the global mining sector. Business \& Society, 53(4), pp.551-582.

Fasua, K.O., 2011. Environmental accounting: concept and principles. Certified National Accountant, 19(2).

Fiori, G., di Donato, F. and Izzo, M.F., 2015. Corporate social responsibility and stock prices: A study on the italian market. Corporate Ownership \& Control, 12(2), pp.600-609.

Freeman, R.E. and Reed, D.L., 1983. Stockholders and stakeholders: A new perspective on corporate governance. California management review, 25(3), pp. 88-106.

Galant, A. and Cadez, S., 2017. Corporate social responsibility and financial performance relationship: a review of measurement approaches. Economic research-Ekonomska istraživanja, 30(1), pp.676-693.

Gazzola, P., 2014. Corporate social responsibility and companies' reputation. Network Intelligence Studies, 2(03), pp.74-84.

Ghozali, I., 2016. Multivariate Analysis Application with IBM SPSS 23. Semarang Program: Diponegoro University Publishing Agency.

Global Reporting Initiative. 2015. GRI Sustainability Reporting Guidelines G4. Retrieved from www. globalreporting.org. 
Guenster, N., Bauer, R., Derwall, J. and Koedijk, K., 2011. The economic value of corporate ecoefficiency. European financial management, 17(4), pp.679-704.

Henri, J.F. and Journeault, M., 2010. Eco-control: The influence of management control systems on environmental and economic performance. Accounting, Organizations and Society, 35(1), pp.63-80.

Hussainey, K. and Salama, A., 2010. The importance of corporate environmental reputation to investors. Journal of Applied Accounting Research.

IFAC (International Federation of Accountant). 2005. International Guidance Document: Environmental Management Accounting.

Indrianto, S. and Supomo, B., 2014. Metodologi Penelitian Bisnis Untuk Akuntansi \& Manajemen. Yogyakarta: Penerbit BPFE.

Kayondo, D., Mukasa, Kim, K., \& Lim, H. 2015. How Do Corporate Social Responsibility Activities Influence Corporate Reputation? Evidence From Korean Firms. The Jurnal of Applied Business Research, 31(2), 11-32.

Koning, C. N. M. De. 2017. Reputation, Corporate Social Responsibility, and Financial Performance of Banks. MaRBLe, 1.

Lourenco, I.C., Callen, J.L., Branco, M.C. and Curto, J.D., 2014. The value relevance of reputation for sustainability leadership. Journal of Business Ethics, 119(1), pp.17-28.

Maden, C., Arıkan, E., Telci, E.E. and Kantur, D., 2012. Linking corporate social responsibility to corporate reputation: A study on understanding behavioral consequences. In Procedia - Social and Behavioral Sciences (Vol. 58, pp. 655-664).

Maqbool, S. and Zameer, M.N., 2018. Corporate social responsibility and financial performance: An empirical analysis of Indian banks. Future Business Journal, 4(1), pp.84-93.

Miralles-Quiros, M.D.M., Miralles-Quiros, J.L. and Arraiano, I.G., 2016. Corporate Social

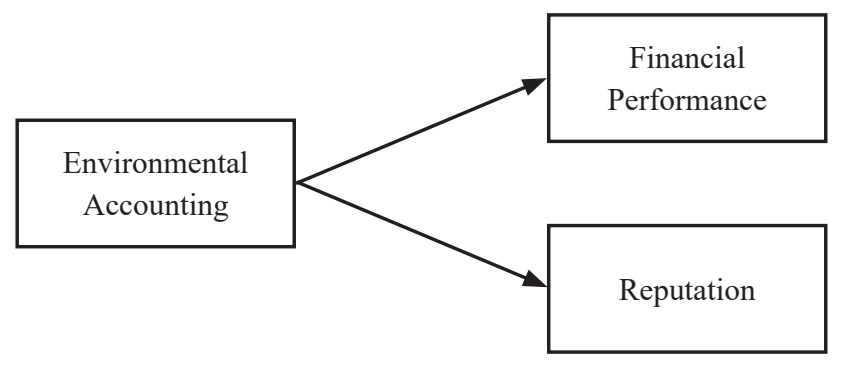

Figure 1. Theretical Framework
Responsibility and Environmental Management. In Corporate Social Responsibility and Environmental Management. Wiley Online Library. https://doi. org/10.1002/csr. 1392

Mishra, S. and Suar, D., 2010. Does corporate social responsibility influence firm performance of Indian companies?. Journal of business ethics, 95(4), pp.571-601.

Pan, X., Sha, J., Zhang, H. and Ke, W., 2014. Relationship between corporate social responsibility and financial performance in the mineral Industry: Evidence from Chinese mineral firms. Sustainability, 6(7), pp.4077-4101.

Rodriguez-Fernandez, M., 2016. Social responsibility and financial performance: The role of good corporate governance. BRQ Business Research Quarterly, 19(2), pp.137-151.

Scott, W. R. 2012. Financial Accounting Theory. In Financial Accounting Theory (Sixth Edit). Canada: Pearson Prentice Hall.

Stekelenburg, A. V., Georgakopoulos, G., Sotiropoulou, V., Vasileiou, K. Z., \& Vlachos, I. 2015. The Relation between Sustainability Performance and Stock Market Returns: an Empirical Analysis of The Dow Jones Sustainability Index Europe. International Journal of Economics and Finance, 7(7), 74-88.

Stuebs, Martin T. and Sun, L. 2011. Corporate Social Responsibility and Firm Reputation. Journal of Accounting, Ethics \& Public Policy, 12(1). Retrieved from https://ssrn.com/abstract $=1863343$

Walter, B. L. 2012. Does Corporate Social Responsibility Really Contribute Reputation? Retrieved from http:// blwalter.com/wp-content/uploads/2012/11/201210-19-IRMC

Weir, C. H. 2010. How does the Stock Market React to Corporate Environmental News? Undergraduate Economic Review, 6(1), 1-31.

www.cnbcindonesia.com.

www.idx.co.id.

www.menlh.com.

Table 1. The Result of Descriptive Sratistics Analysis

\begin{tabular}{lccccr}
\hline & N & Minimum & Maximum & Mean & $\begin{array}{c}\text { Std } \\
\text { Deviation }\end{array}$ \\
\hline $\begin{array}{l}\text { Financial } \\
\text { Performance (FP) }\end{array}$ & 60 & -0.1682 & 0.4922 & 0.0819 & 0.0903 \\
$\begin{array}{l}\text { Reputation } \\
\text { (REPU) }\end{array}$ & 60 & -0.930 & 1.430 & - & 0.510 \\
$\begin{array}{l}\text { Environmental } \\
\text { Accounting (EA) }\end{array}$ & 60 & 0.400 & 0.800 & 0.580 & 0.080 \\
\hline $\begin{array}{l}\text { Source: data processed, 2019 } \\
\text { (20) }\end{array}$ & & & & \\
\hline
\end{tabular}


Table 2. Regression Analysis Equation 1

\begin{tabular}{|c|c|c|c|c|c|c|}
\hline \multirow[t]{2}{*}{ Model } & \multicolumn{2}{|c|}{$\begin{array}{l}\text { Unstandardized } \\
\text { Coefficients }\end{array}$} & \multirow{2}{*}{$\begin{array}{c}\begin{array}{c}\text { Standardized } \\
\text { Coefficients }\end{array} \\
\text { B }\end{array}$} & \multirow[t]{2}{*}{$\mathrm{t}$} & \multirow[t]{2}{*}{ Sig } & \multirow[t]{2}{*}{ Decission } \\
\hline & $\mathrm{B}$ & Std. Error & & & & \\
\hline Constanta & $-3,221$ & 1,155 & & $-3,004$ & 0,000 & \\
\hline Environmental Accounting (EA) & 1,459 & 0,432 & 0,271 & 4,788 & 0,013 & Accepted \\
\hline Adjusted R2 & 0,136 & & & & & \\
\hline $\mathrm{F}$ & 10,511 & & & & & \\
\hline
\end{tabular}

Source: data processed, 2019

Table 3. Regression Analysis Equation 2

\begin{tabular}{|c|c|c|c|c|c|c|}
\hline \multirow[t]{2}{*}{ Model } & \multicolumn{2}{|c|}{$\begin{array}{c}\text { Unstandardized } \\
\text { Coefficients }\end{array}$} & \multirow{2}{*}{$\begin{array}{c}\begin{array}{c}\text { Standardized } \\
\text { Coefficients }\end{array} \\
\text { B }\end{array}$} & \multirow[t]{2}{*}{$\mathrm{t}$} & \multirow[t]{2}{*}{ Sig } & \multirow[t]{2}{*}{ Decission } \\
\hline & $\mathrm{B}$ & Std. Error & & & & \\
\hline Constanta & $-4,115$ & 1,025 & & $-4,014$ & 0,000 & \\
\hline Environmental Accounting (EA) & 2,699 & 0,526 & 0,481 & 5,659 & 0,000 & Accepted \\
\hline Adjusted R2 & 0,144 & & & & & \\
\hline $\mathrm{F}$ & 11,866 & & & & & \\
\hline
\end{tabular}

Source: data processed, 2019 